\title{
嚥下造影検査食の使用と調製に関するアンケート調査
}

\author{
藤谷 順子 $* 1$
}

\section{A Questionnaire Survey about the Use and Preparation of Test Foods for Videofluoroscopic Swallowing Examinations}

\author{
Junko FuJITANI ${ }^{* 1}$
}

\begin{abstract}
Objective : To understand how test foods used in videofluoroscopic swallowing examinations (VF) are prepared and used. Methods : A survey was conducted using participants in a workshop organized by the Japanese Association of Rehabilitation Medicine (October 27, 2012). Results : Among 129 participants, the survey collection rate was $48.8 \%$. The percentage who had conducted VF was $66.7 \%$. The test foods used were thickened liquid $97.6 \%$, jelly $92.9 \%$, and test foods other than liquid, thickened liquid or jelly were used by $64.3 \%$. A little less than $20 \%$ answered that the test foods did not always or possibly did not always have the same physical property and texture. The contrast agents used in test foods were barium sulfate $50.0 \%$, amidotrizoic acid (Gastrografin ${ }^{\circledR}$ ) $33.3 \%$ and iodinated contrast agent for angiography $7.1 \%$. Conclusions : In addition to thickened liquid and jelly, many solid test foods were also used. The uniformity and safety of these test foods and their properties need to be examined and considered in their preparation. (Jpn J Rehabil Med $2013 ; 50$ : 917-921)

要 旨 目的：鱟下造影検查で使用される検査食が，どのように調製され，使用されている かを把握する. 方法：日本リハビリテーション医学会主催の研修会参加者を対象にアンケート 調查を行った（2012 年 10 月 27 日）。結果：アンケート回収率は $48.8 \%$ たった。嚥下造影検査

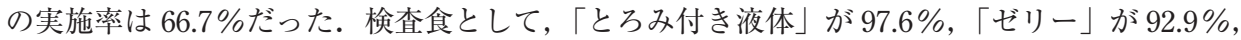
「液体」「とろみ付き液体」「ゼリー」以外の検查食が $64.3 \%$ に使用されていた。検查食が毎回 同じ物性・食感のものができていない，またはできていない可能性があるとする回答が 2 割弱 あった，検查食で使用する造影剤は，硫酸バリウムが50.0\%，アミドトリゾ酸（ガストログ ラフイン ${ }^{\circledR}$ ) が $33.3 \%$ ，血管造影用ヨード造影剤は $7.1 \%$ あった。結論：検査食として，「と ろみ付き液体」「ゼリー」に加え，固形状の検查食が多く使用されていた．検查食の調製には， 物性面での均一性や安全性について検討が必要であると思われた。
\end{abstract}

Key words : 嚥下造影（videofluorography），検査食（videofluoroscopic contrast agents）， ンケート (questionnaire)

はじめに

曣下造影検查 (Videofluorography：以下 VF 検查) は，摂食・嚥下機能障害診療における基本的な検査と して広く利用されている，VF 検査においては，造影 剤の形態が嚥下の難易度や安全性に大きく影響する。 1986 年に Logemann が Modified Barium Swallow
案した際にも 3 種類（liquid，paste，cookie）を使用 して検査を行うことが望ましいと述べており卓，日本 摂食・䜩下リハビリテーション学会の嚥下造影の検査 法（詳細版）でも，「実際の摃食場面を想定し，種々 の検査食を用いて検査をすすめる」としており，増粘 剤を付加したバリウム液やゼラチンゼリー，寒天ゼ リー, ヨーグルト，クッキー，蒸しパンなどを例示し

2013 年 5 月 4 日受付， 2013 年 9 月 10 日受理

*1 独立行政法人国立国際医療研究センター病院リハビリテーション科/テ 162-8655 東京都新宿区戸山 1-21-1

Department of Rehabilitation Medicine, National Center for Global Health and Medicine

E-mail : jufujita@hosp.ncgm.go.jp 
ている ${ }^{2)}$ 筆者らが実施した 25 施設調査においては, 調査した施設の $96 \%$ がゼリー状の検査食を，80\%が 液体の検查食を，76\%がとろみ・ペースト状の検査 食を，72\%がその他の食事に近い固形物の検査食を 使用していた ${ }^{3)}$.

VF 検查は，診療報酬において，造影剂注入手技と して 240 点の算定が認められている。しかしながら， $\mathrm{VF}$ 検査に使用する造影剂入りの検査食（検査薬）は, 医薬品として市販されていない。そのため，上述した ような各種形態の検査食は, VF 検査を実施する各施 設において，医薬品の造影剂と，増粘剂や各種食品と を混和して調製が行われている.

今後, 超高齢社会の進展に起因する摂食・嚥下障害 患者の増加に伴い, $\mathrm{VF}$ 検査の重要性は高くなり, VF 検査食についても，共通化は必要になってくると考え る。そこで今回, 各種形態の VF 検查食がどのように 調製され，使用されているかの現況を把握するため, アンケート調査を行った。

\section{対象と方法}

アンケートは，公益社団法人日本リハビリテーショ ン医学会が主催した「病態別実践リハビリテーション (以下, リ八) 研修会 (神経系障害)」の参加者を対象 に行った（開催日：2012 年 10 月 27 日（土），開催場 所：品川フロントビル, 対象：日本リ八医学会会員).

アンケート用紙は，研修会資料に同封し，著者が講 師を務めたプログラム「曣下障害のマネージメント」 の終了時に回収を行った。なお，アンケートは，A4 判用紙 1 枚で 6 項目 11 問であり，主に複数選択肢か らの単一選択方式とし，無記名で行った。

\section{結果}

研修会への参加者は 129 名であった．参加者の背景 は「勤務医」が 86.8\%（112 名)，「開業医」が 7.8\% (10 名)，「その他」5.4\%（7名）であった。「その他」 は，大学教員などであった。アンケートの回収率は 48.8\%（63 名）であった.

問 $1 「 \mathrm{VF}$ 検查を実施していますか?」は，「はい」 が 66.7\% (42 名)，「いいえ」は33.3\%（21名）で あった、「いいえ」の理由は，「装置がない」 $14.3 \%$ (3 名)，「経験がない」76.2\% (16 名)，「その他」 9.5\%（2名）であった.「その他」の理由は，機会が ない, VF 検査の担当医ではないであった.

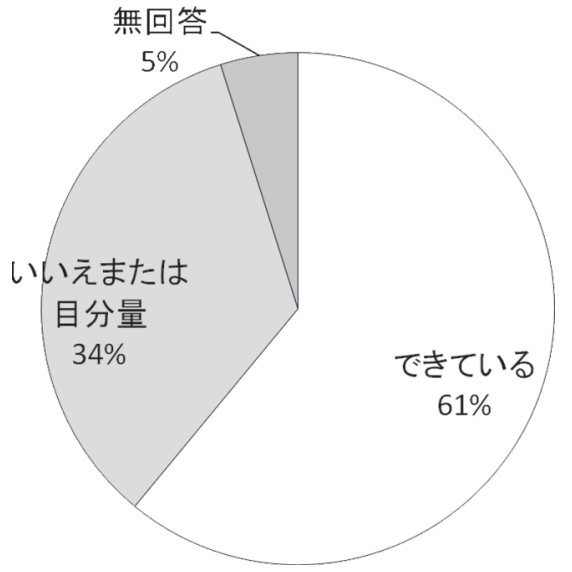

図 1 「増粘剂の量を決めていますか？」 への回答

$N=42 ：$ 問 2 でとろみ付き液体を使用してい ると答えた回答者

問 2 以降は, 問 1 で「はい」と回答した者 42 名, つまり，「VF 検査を実施している」と回答した者のみ に依頼した。

問 2 「検查食として「とろみ付きの液体」は使って いますか?」は，「はい」が97.6\% (41名)，無回答 2.4\%（1名）であった。「いいえ」はゼロであった. 「はい」と回答した者に対して行った「増粘剂の量を 決めていますか？」は，「はい」が $61.0 \%$ (25 名)， 「いいえ，または，目分量でしか決めていない」は $34.1 \%$ （14名），無回答 $4.9 \%$ (2名) であった（図 1 ).

問 3 「検査食として「ゼリー」は使っていますか？」 は，「はい」が 92.9\% (39名)，「いいえ」は $4.8 \%(2$ 名), 無回答 $2.4 \%$ (1名) であった.「はい」と回答 した者に対して行った「だれが「ゼリー」を作ってい ますか？」は，「栄養科」が $53.8 \%$ (21名)，「言語聴 覚士 (以下 ST)」は 30.8\% (12 名)，「医師」5.1\%（2 名),「その他」 $2.6 \%$ (1名), 無回答 $5.1 \%$ (2 名) で あった（図 2).「薬剤師」はゼロであった。「その他」 はNST を担当する看護師であった。なお，複数回答 (「栄養科」と「ST」) による無効 1 名があった.

問 4 「検查食として，「液体」「とろみ付き液体」「ゼ リー」以外のものを使っていますか?」は，「はい」 が 64.3\% (27名)，「いいえ」は31.0\%（13名），無 回答 $4.8 \%$ (2名) であった.「いいえ」の理由は, 「液体」「とろ久付き液体」「ゼリー」で十分に診断可 能とする意見や前医で検査された患者が送られてくる 


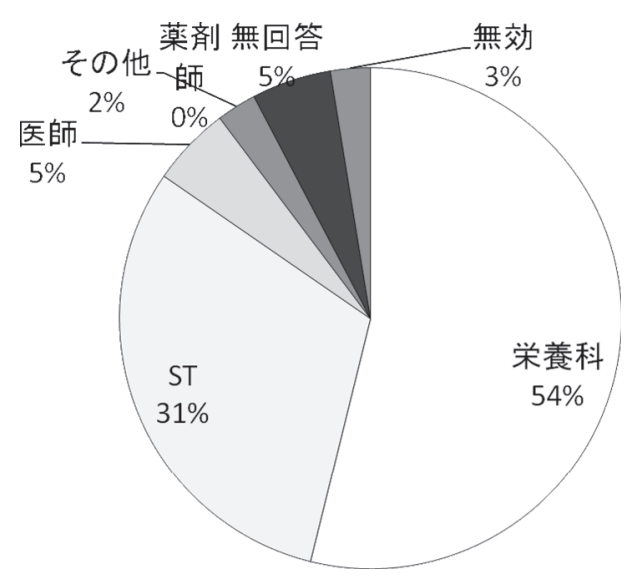

図 2 「誰が「ゼリー」を作っていますか」へ の回答

$N=39$ ：問 3 でゼリーを使用していると答えた回 答者

とする意見のほか，検査できる人がいない，詳しく知 らないためとの意見もあった。「はい」と回答した者 に対する「具体例を挙げてください。(自由記載)」 は，クッキーやパン，病院で使用している嚥下調整食 に造影剂を混ぜて検査食としている旨の記載であっ た。「本人が食べたい物」との記載もあった。また， 「その検查食は，どのように作っていますか?」は， 「検査前にあらかじめ作っている」が 81.5\% (22 名), 「検査の場で混ぜている」は $18.5 \%$ （5 名）であった。 「その食品（検査食）の提供元はどこですか？（複数 回答可)」は，「栄養科」が $81.5 \%$ (22 名)，「ST」は $25.9 \%$ （7名），「患者の持ち込み」 $11.1 \%$ （3 名）で あった（図 3)。

問 4 で「はい」と回答した者は，問 2 , 問 3 でも「は い」と回答しており，「とろみ付き液体」と「ゼリー」 を使用している施設がさらにそれ以外の形態のものも 使用していた。

問 5 「検査食は毎回同じ物性・食感のものが作製で きていますか?」は，「できている」が21.4\%（9 名)，「ほぼできている」は47.6\% (20名)，「できて いない可能性がある」 $14.3 \%$ (6名)，「できていない」 4.8\%（2 名)，無回答 $11.9 \%$ （5名）であった（図 4).

問 6 「検査食の造影剤は何を使用していますか？ (複数回答可)」は，「硫酸バリウム」が $50.0 \%(21$ 名)，「アミドトリゾ酸（ガストログラフイン $\left.{ }^{\circledR}\right) 」 は$ $26.2 \%$ (11 名)，「血管造影用ヨード造影剂」7.1\%（3 名), 無回答 $21.4 \%$ (9名) であった。各造影剤の選

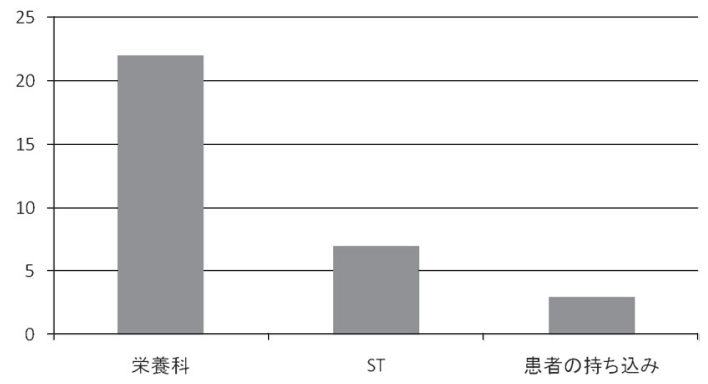

図 3 「液体」「とろみ付き液体」「ゼリー」以外の検 査食の提供元（複数回答可）

$N=27$, 上記 3 種以外の検査食の利用があると答えた回 答者

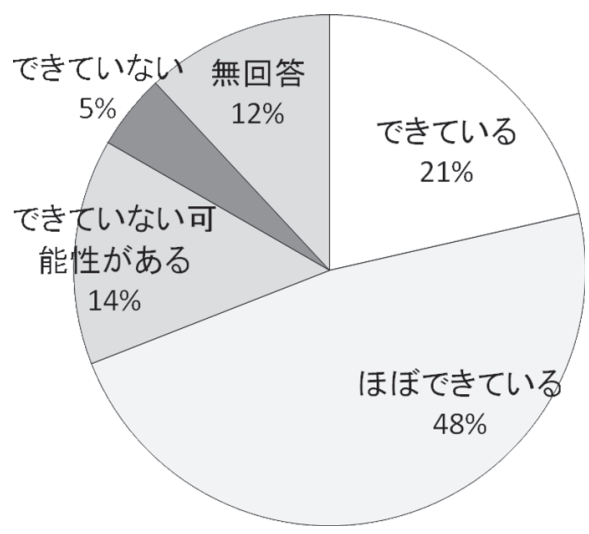

図 4 「検査食は毎回同じ物性・食感のもの が作製できていますか？」への回答

$N=42$ ：問 2 でとろみ付き液体を使用している と答えた回答者

択理由は，硫酸バリウムが「すぐに手に入り保険上の 問題がない」「手に入りやすく安価」「これしかない」 「他の造影剤の使用経験がない」「内科で使用している から」「放射線科まかせ」「とくになし」「肺毒性」「学 会のガイドラインにそって選択」であり，ガストログ ラフイン ${ }^{\circledR}$ が手に入りやすく安価」「鱟下性肺炎時 のため」，血管造影用ヨード造影剂が「肺炎のリスク を考えて」であった。

\section{考察}

VF 検査では，実際の摂食場面を想定し，液状，と ろみ・ペースト状，ゼリー状扮よび食事に近い固形物 の検査食などが用いられている3 。今回，これらの $\mathrm{VF}$ 検査食がどのように調製され，使用されているか をアンケートにより調査した。な扔，筆者の調べ得た 
範囲では, VF 検査食について, 誰が・いつ調製して いるか等を調查した報告はない.

脳卒中治療ガイドライン 2009 では，「脳卒中患者に おいては，與下障害が多く認められる。それに対し， 嚥下機能のスクリーニング検査，さらには嬹下造影検 査，内視鏡検查などを適切に行い，その結果を元に， 栄養摂取経路（経管・経口）や食形態，姿勢，代償嬹 下法の検討と指導を行うことが勧められる（グレード B)」と記載されている4).

Ogita らが行った老年病専門医を対象としたアン ケート調査では, Tube-feeding 導入前の摂食・黇下障 害に対する介入として，38.9\%が VF 検査を回答して いる5 ．今回の調查では， $66.7 \%$ が VF 検査を実施し ていると回答して抢り, Ogitaらの調査と比較して, より摃食・䀣下障害の評価を積極的に実施している医 師群に対して調查を行うことができたと思われた。な お，これは，日本リ八医学会主催の研修会に参加した 医師を対象としているためと思われた。

本調查では，90\%以上が「とろみ付きの液体」お よび「ゼリー」を VF 検査食として使用していること がわかった．以前の調査では，とろみ・ペースト状の 検査食の使用率は $76 \%$ であり ${ }^{3)}$, 今回の調査ではより 高頻度に使用されていた。また，本調査では，6割以 上が「液体」「とろみ付き液体」「ゼリー」以外の VF 検査食を使用しており，病院で使用されている嚥下調 整食に造影剂を混ぜたもの，またはクッキーやパンが 使用されていた。クッキーやパンの検査食は，液体の ような命令讌下の検査ではなく，プロセスモデルに代 表されるような，咀嚼，食塊形成から鱟下に繋げる過 程をみるために使用されている6 。これらの検查食 は，検査前にあらかじめ調製しているとする回答が多 く，調製に手間がかかる検査食である，それにも関わ らず，多くの施設でこれらの検査食が使われているこ とは，咀嚼，食塊形成から嚥下に慗げる過程をみるた めの検査が重要であることを示しているものと思われ た。なお，主に経口撕取の再開を評価する目的で検査 を行う急性期か，リハや食事の内容を検討する目的で 行う回復期かにより，使用する VF 検査食の種類は変 わる可能性がある，本調査では，回答者や患者背景を 収集していないため, 結果の解釈には注意を要する。

本調査では，検査食が毎回同じ物性・食感のものが できていない，またはできていない可能性があるとす る回答が 2 割近くもあった。また，「とろみ付きの液
体」について，増粘剤の量を決めていない，または目 分量でしか決めていないとする回答が 3 割以上あっ た，検査食の物性により，曣下動態や食塊輸送が影響 されるとの報告が多数あり ${ }^{7 \sim 11)}$, 物性が一定でない場 合には，検查の結果自体が機能を正しく反映しない可 能性がある。そのため, VF 検查食の調製においては, いつ，だれが調製しても同じ物性になるようにレシピ や手順があることが望ましい。

また，本調查では，「ゼリー」の検査食の調製が， 主に栄養科または言語聴覚士によって行われているこ とがわかったＶVF 検查では，摃食・嚥下障害の診断 に加え，どのような形態の食事をどうやったら経口摂 取できるかが検討されている。そのため，自らもそれ らに関倸の深い栄養科や言語聴覚士が VF 検査食の調 整を分担していると考えられた。一方で，VF 検査食 には医薬品の造影剤が使われており，その点では薬剤 師が調製する院内製戍と考えることもできるが ${ }^{12}$ ，薬 剤師が調製しているという回答はなかった。

$\mathrm{VF}$ 検查は，摂食・黇下障害がある患者を対象とし た検查であるため，検査中にも誤嚥する危険性を伴 う。本調查では，硫酸バリウムが 5 割，ガストログラ フイン ${ }^{\circledR}$ が 3 割弱で使用されており，血管造影用の ヨード造影剂は 1 割未満でしか使用されていなかっ た。 日本撕食・嚥下リ八学会では，ガストログラフイ ン®は肺毒性があるため嚥下障害での使用は不適当と し，硫酸バリウムは大量の誤嚥さえなければ比較的安 全としている2．しかしながら，VF 検查中に硫酸バ リウムを誤嚥し，死亡や肺炎などを起こした症例の報 告も散見される ${ }^{13,14)}$ 。そのため, VF 検查の実施に際 しては，使用する一口量の調整や誤嚥時への対処方法 など，安全面を考慮する必要があると思われた。日本 耳鼻咽喉科学会の嚥下障害診療ガイドラインでは「誤 嚥が明らかな例では，非イオン性の血管造影剂を用い る」としておりり ${ }^{15)}$ 適応外使用ではあるが，誤嚥時の 安全性のために使用している施設があると思われた.

本調査では, VF 検査の検查食として，「とろみ付き 液体」「ゼリー」に加え，咀嚼や食塊形成から鱟下に 繋がる過程をみるための固形状の検查食がリ八学会員 の中で多く使用されていることがわかった．また，こ れらの VF 検査食の調製に関しては，物性面や安全性 についてさらに検討が必要であることがわかった。な お，海外では, Thin liquid, Nectar, Thin Honey, Honey, Pudding の物性のバリウム製凨が販売されており, 
近年では，バリウムクッキーも販売されている。これ らは ready-to-use に使用でき，物性面のばらつきも抑 えられるため, 将来, 日本でも嚥下造影検査用製剤が 販売されることを願っている.

本アンケート調査について，実施の許可をいただいた病 態別実践リ八医学研修会小委員会委員各位ならびにアン ケートの配布・回収に協力いただいた学会事務局, 回答し てくださった参加者の皆さまに感謝いたします.

\section{文献}

1) Logemann JA : Chapter 4, Variations in the Modified Barium Swallow Procedure. in Manual for the Videofluorographic Study of Swallowing. PRO-ED, Texas, 1986 ; pp 45-72

2) 植田耕一郎, 岡田澄子, 北住映二, 小山珠美, 高橋浩二, 武原 格, 谷本啓二, 椿原彰夫, 馬場 尊, 堀口利之, 山 本弘子, 藤島一郎, 日本摂食・嚥下リハビリテーション 学会医療検討委員会: 嚥下造影の検査法 (詳細版) 日本 摂食・讌下リハビリテーション学会医療検討委員会 2011 版案. 日本摂食・噁下リハビリテーション学会雑 誌 $2011 ; 15: 76-95$

3）伊藤彰博, 東口高志, 巨島文子, 太田喜久夫, 栢下 淳, 重松 孝, 白木 亮, 藤谷順子, 山中英治: 嚥下造影検査 食の使用実態に関する全国 25 施設の調査報告. 静脈経 腸栄養; 投稿中

4）脳卒中合同ガイドライン委員会: VII. リハビリテー ション 2. 主な障害・問題に対するリハビリテーション 2-7. 嚥下障害に対するリハビリテーション. 脳卒中治 療ガイドライン 2009 (篠原幸人, 小川 彰, 鈴木則宏, 片山泰朗, 木村彰男 編). 協和企画, 東京, 2009 ; pp 318-321

5) Ogita M, Utsunomiya $H$, Akishita $M$, Arai $H$ : Indications and practice for tube feeding in Japanese geriatricians :
Implications of multidisciplinary team approach. Geriatr Gerontol Int $2012 ; 12$ : 643-651

6) Palmer JB, Hiiemae KM : 口腔と咽頭における食塊送り 込み (propulsion)の統合 蟮下生理に関する新しいモ デル. 日本摂食・讌下リハビリテーション学会雑誌 $1997 ; 1: 15-30$

7) Mendell DA, Logemann JA : Temporal sequence of swallow events during the oropharyngeal swallow. J Speech Lang Hear Res 2007 ; 50 : 1256-1271

8) Butler SG, Stuart A, Castell D, Russell GB, Koch K, Kemp S : Effects of age, gender, bolus condition, viscosity, and volume on pharyngeal and upper esophageal sphincter pressure and temporal measurements during swallowing. J Speech Lang Hear Res 2009 ; 52 : 240-253

9) Bisch EM, Logemann JA, Rademaker AW, Kahrilas PJ, Lazarus C : Pharyngeal effects of bolus volume, viscosity, and temperature in patients with dysphagia resulting from neurologic impairment and in normal subjects. J Speech Hear Res 1994 ; 37 : 1041-1059

10) Clavé P, de Kraa M, Arreola V, Girvent M, Farré R, Palomera E, Serra-Prat M : The effect of bolus viscosity on swallowing function in neurogenic dysphagia. Aliment Pharmacol Ther 2006 ; 24 : 1385-1394

11）稲本陽子,才藤栄一：CTを用いた䱏下動態の評価と臨 床応用. Medical Rehabilition $2011 ; 136: 13-20$

12）日本病院薬剤師会: 院内製剂の調製及び使用に関する 指針 (Version 1.0). 平成 24 年 7 月 31 日. Available from URL : http://www.jshp.or.jp/cont/12/0731-1-1.pdf

13) Albeldawi M, Makkar $R$ : Images in clinical medicine. Barium aspiration. N Engl J Med $2012 ; 366$ : 1038

14）後藤智紀, 解良恭一, 遠藤克明, 森 貴紀, 堀江健夫, 滝 瀬 淳, 稲沢正士 : 高濃度硫酸バリウムによる誤嚥性肺 炎の 1 例. 日本内科学会関東地方会 520 回 $2004 ; 21$ (抄)

15）IX與慗下造影検査．嚥下障害診療ガイドライン一耳鼻咽 喉科外来における対応一 (日本耳鼻咽喉科学会 編). 金 原出版, 東京, 2012; pp 21-22 